\title{
The Causal Agent of Damping-off in Pinus patula (Schiede) and Pinus tecunumanii (Schwerdtf.)
}

\author{
Maria Alejandra Fajardo ${ }^{1}$, Juan Diego León ${ }^{1}$, Guillermo Antonio Correa ${ }^{2}$, \\ Juan Gonzalo Morales²
}

${ }^{1}$ Departamento de Ciencias Forestales, Universidad Nacional de Colombia Sede Medellín, Medellín, Colombia ${ }^{2}$ Departamento de Ciencias Agronómicas, Universidad Nacional de Colombia, Medellín/Antioquia, Colombia

\begin{abstract}
Damping-off is considered one of the most serious risks for production of Pinus seedlings due to the significant losses it can cause in forest nurseries. In Colombia there is little information about the etiology of this limiting disease. Different species of the genus Fusarium have been reported as causal agents, which makes the study of the pathogenicity of this genus relevant. In this study, strain $001 \mathrm{~F}$ of Fusarium oxysporum was obtained from the diseased tissues of $P$. patula seedlings. The identity of the species was determined by sequencing the internal transcribed spacer (ITS) regions. Pathogenicity tests confirmed the ability of strain $001 \mathrm{~F}$ to cause damping-off symptoms in $P$. patula and P. tecunumanii. Thus, $F$. oxysporum strain $001 \mathrm{~F}$ represents a significant risk to produce tree species in Colombia and in other parts of the world.
\end{abstract}

Keywords: Fusarium sp., forest nurseries, pathogenicity. 


\section{INTRODUCTION}

Colombia is the seventh country in the world in area covered with natural forests with about $49 \%$ of its terrestrial area (Sánchez-Cuervo et al., 2012). 24 million hectares are suitable for commercial reforestation, however, only 450.000 ha have been planted and for 2038 it is projected to increase to 1.5 million ha (UPRA, 2018). The genus Pinus (L.) predominates commercial reforested area in Colombia, with 108.060 ha, followed by Eucalyptus (L'Hér), with 57.447 ha, Acacia (Mill) with 36.986 ha and other genera (PROFOR, 2017). P. tecunumanii (Schwerdtf. ex Eguiluz and Perry) excels within Pinus species, mainly due to its excellent phenotypic and silvicultural characteristics, fast growth and arguably, the best shank from all tropical Pinus, which confers a great potential for reforestation in tropical and subtropical regions (Kanzler et al., 2014; Claros Cuadrado et al., 2017). P. patula (Schiede ex Schltdl. and (ham) is another important species with potential for production in Colombia because of its high content of cellulose and hemicellulose (Gómez et al., 2012). However, for sustainable production of commercial forests diseases such as damping-off should be appropriately managed. Damping-off is considered one of the biggest phytosanitary risks affecting the future sustainability of the wood industry (Seseni et al., 2015; López-López et al., 2016). This is because it significantly decreases the possibility of obtaining healthy nursery seedlings suitable for the field (Vivas et al., 2012). This disease can progress rapidly and cause significant losses in forest productivity (García Díaz \& Cibrián Tovar, 2011).

This pathology, common in seeds and seedlings of many tree species, is caused by various pathogens such as Phytophthora spp. (de Bary), Pythium spp. (Pringsh), Rhizoctonia spp. (DC.) and Fusarium spp. (Link ex Grey), among others (Dar et al., 2011). These pathogens have been reported as causal agents of damping-off in seedlings of several Pinus species, such as $P$. nigra (Arnold), P. pinea (L.), and P. patula (Machón et al., 2009; Herrón et al., 2015). In Colombia, there are currently few studies aimed at understanding forest pathologies despite being one of the most limiting factors to produce seedlings of several Pinus species used for commercial reforestation.
Fusarium spp. are cosmopolitan fungi that have pathogenic forms and are capable of parasitizing different gymnosperm and angiosperm species (Bosland, 1988). It has been identified as a causal agent of rot and wilt symptoms (Dean et al., 2012; Zuo et al., 2015; Carrasco et al., 2016), causing important economic losses in more than 200 crops around the world (Pérez et al., 2017). Fusarium species are frequently the causal agents responsible for damping-off in forest nurseries, and sometimes they cause important damage in very young plantations in the field (Vivas et al., 2012; Martín-Rodrigues et al., 2015; Fajardo-Mejía et al., 2016). Stewart et al. (2012) found that isolates of $F$. oxysporum (Schltdl.) and F. commune (Skovgaard, O'Donnell and Nirenberg) caused damping-off in Douglas fir seedlings under greenhouse conditions. Similar results point to F. circinatum (Nirenberg and O'Donnell) as the causal agent of damping-off in seedlings of $P$. maximino (Moore) and P. tecunumanii (Maphosa et al., 2016; Martínez-Álvarez et al., 2016; García Díaz et al., 2017; Flores-Pacheco, 2017; Swett et al., 2018).

In Colombia, Steenkamp et al., (2012) found that F. circinatum, besides being related to the symptoms of damping-off in P. patula, P. maximinoi, and P. tecunumanii seedlings, is also related to shoot dieback and outbreaks of resinous stem canker on the plantation trees.

To carry out an adequate management of the problem, it is necessary to start with timely and precise identification of the causal agent of the disease because an incorrect diagnosis could cause the disease control to fail, increasing costs and the risk of losses in the plantation. In this research, the causal agent of damping-off was determined for P. patula and $P$. tecunumanii seedlings, two of the most important species for commercial reforestation in Colombia. Ultimately, this finding is vital for management of the disease, reducing the risks posed by its causal agents both in the nursery phase and in field plantations.

\section{MATERIAL AND METHODS}

\subsection{Microorganism isolation}

Isolates were obtained from $P$. patula seedlings harvested in a commercial nursery, with symptoms typical of damping-off, such as wilting or basal rot of the stem and root. The tissue of the diseased plant was disinfected in $1 \%$ hypochlorite for 1 minute, rinsed 
for 1 minute with sterile distilled water, followed by one-minute disinfection with $70 \%$ ethanol, and a final wash with sterile distilled water. Then, small pieces of tissue containing lesions were cut, seeded directly on potato-dextrose-agar culture medium (PDA, Difco USA), incubated at approximately $28^{\circ} \mathrm{C}$ and observed daily. Fungal isolates were grown in petri dishes containing PDA medium at $28^{\circ} \mathrm{C}$, for 14 days for further work.

\subsection{Morphological and molecular identification}

Colony description was made based on the color, the diameter, and characteristics of the aerial mycelium. Observation and description of the reproductive structures were performed using a Nikon SMZ1000 optical microscope coupled to a digital camera. Morphological characteristics of conidia were studied based on the shape, the septation and the mean of dimensions (width and length) calculated from 30 measurements performed in the light microscope (Fourie et al., 2011; Santos et al., 2019).

\subsection{DNA extraction}

DNA was extracted from 14-day cultures of fungal isolate in Petri plates containing PDA medium. To do so, mycelium was scraped directly from the surface of PDA plates. The mycelium obtained was lyophilized and pulverized with liquid nitrogen using a mortar and a pestle until obtaining a fine powder, which was kept at $-20^{\circ} \mathrm{C}$ until further use. Nucleic acids were extracted from $100 \mathrm{mg}$ of mycelium powder using the CTAB, phenol:chloroform (1:1) method (CTAB 3\%, $100 \mathrm{mM}$ Tris $\mathrm{HCl} \mathrm{pH}$ 8.0, $1.4 \mathrm{mM} \mathrm{NaCl}, 20 \mathrm{mM}$ EDTA pH 8.0, supplemented with $150 \mu \mathrm{L}$ of SDS (20\%)), and precipitated with cold isopropanol and $3 \mathrm{M}$ sodium acetate. Nucleic acids were resuspended in $50 \mu \mathrm{L}$ of TE buffer (Tris- $\mathrm{HCl} 10 \mathrm{mM} \mathrm{pH} \mathrm{8.0).} \mathrm{The} \mathrm{RNA} \mathrm{was}$ digested with RNase $\left(10 \mu \mathrm{g} \cdot \mathrm{mL}^{-1}\right)$ and the DNA solution was stored at $-20^{\circ} \mathrm{C}$ for further use. The purified DNA was analyzed and quantified by spectrophotometry using a NanoDrop equipment (Thermo Scientific) and electrophoresis in $0.8 \%$ agarose gels in TBE $0.5 \mathrm{X}$ pH 8.0 (0.09 M Tris-borate, 0.002 M EDTA, Amresco) visualized under UV by staining with EZ-96 VISION ${ }^{\circledR}$ (Thermo Scientific, Waltham, MA. USA), following the manufacturer instructions.

\subsection{Sequence analysis of the Internal}

Transcribed Spacer (ITS) regions of the fungal $r D N A$

The molecular identification was carried out by sequencing the ITS regions of the rDNA. These regions were amplified by PCR using the universal primers ITS 1 (5 'TCC GTAGGT GAA CCT GCG G 3') and ITS4 (5 'TCC TCC GCTTATTGATAT GC 3') (White et al., 1990). For PCR amplification, 10X KCl buffer, $25 \mathrm{mM}$ $\mathrm{MgCl} 2,2.5 \mathrm{mM}$ dNTP, $10 \mu \mathrm{M}$ primers, Taq DNA Polymerase and 3 ng of the purified DNA were used in a final volume of $30 \mu$ l. The program started with a temperature of $95^{\circ} \mathrm{C}$ for 3 minutes, followed by 35 cycles of amplification (denaturation at $95^{\circ} \mathrm{C}$ for 30 seconds, annealing at $55^{\circ} \mathrm{C}$ for 1 minute and extension at $72^{\circ} \mathrm{C}$ for 1 minute) and a final extension at $72^{\circ} \mathrm{C}$ for 10 minutes. The PCR products were visualized by electrophoresis in $1.2 \%$ agarose gels, stained with EZ-VISION ${ }^{\circledR}$, following the manufacturer's instructions (Thermo Scientific). The bands of the expected size (500 to $600 \mathrm{bp}$ ) were purified using the GenJet kit (Thermo Scientific), following the manufacturer's instructions and sent for sequencing. The sequences obtained were assembled, edited and aligned manually, using the BioEdit software. The sequences were compared with the National Center for Biotechnology Information (NCBI) databases, using the BLAST package (NCBI, 2019).

The species identification included 16 ITS nucleotide sequences from Fusarium spp. retrieved from NCBI database (Genbank code between parentheses). These sequences were selected for comparison with some species of Fusarium distant from F. oxysporum and reported as causing disease in Pinus spp.: 11 sequences of F. oxysporum (MG966527.1, MG798785.1, KY855514.1, KY855512.1, KY855511.1, KY855508.1, KY855507.1, KY855506.1, KY855505.1, MG670446.1 and KF313101.1), 1 of F. commune (KT982281.1), 1 of $F$. proliferatum ((Matsush) Nirenberg ex Gerlach and Nirenberg) (GU074010.1), 1 of F. circinatum (KC464617.1), 1 of F. bactridioides (Wollenw.) (KC464615.1) and 1 of F. fujikuroi (Nirenberg) (MF356517.1) (Herrón et al., 2015; Stewart et al., 2012; González et al., 2008).

A dendrogram was constructed by using the Maximum Likelihood method based on the Jukes-Cantor model (Tuffley et al., 2012). A bootstrap consensus tree was inferred from 1000 replicates (Felsenstein, 1985). Branches corresponding to partitions reproduced in less 
than $50 \%$ bootstrap replicates were collapsed. Analyses were conducted in MEGAX (Kumar et al., 2018).

\subsection{Obtaining the inoculum}

The spore inoculum was prepared using an isolate that was grown for 14 days under the previously described conditions. To do so, sterile distilled water was added to the Petri dishes and the mycelium was scraped to form a suspension. Subsequently, the inoculum was quantified in a Neubauer chamber, to adjust the concentration to $1 \times 10^{6}$ spores $/ \mathrm{ml}$. Additionally, another source of inoculum was prepared for the pathogenicity tests from the macerate of diseased $P$. tecunumanii seedlings obtained approximately 15 days after sowing. This timing was chosen because at 15 days the seedlings showed a higher incidence of the disease compared to the non-inoculated plants. The macerate was obtained by liquefying diseased plantlets covered in their entirety with sterile distilled water, until a homogeneous suspension was obtained (approximately 3 minutes). The suspension was decanted by gravity and the supernatant was recovered, which was used as a source of inoculum of the disease.

\subsection{Pathogenicity tests}

Sexual seeds of $P$. patula and $P$. tecunumanii were sown in germinating trays of 25 plants each. The isolate obtained was evaluated to determine its ability to cause disease in P. patula and P. tecunumanii seedlings. The Koch postulates were fulfilled. The tests were carried out under laboratory conditions using plastic trays disinfected with $1 \%$ hypochlorite, then filled with autoclaved soil. Three trays were used per each treatment for a total of 75 plants per treatment. Seeds were provided by the Santa Elena forest nursery and INAFOR (National Forest Institute, Nicaragua), respectively. Pinus seeds were embedded in an inoculum suspension at a concentration of $1 \times 10^{6}$ spores $\mathrm{ml}^{-1}$ for 12 hours. Then, the soil substrate was inoculated with $5 \mathrm{~mL}$ of the spore suspension at the same concentration described and treated seeds were sown. A plant showing damping-off symptoms was considered as diseased. Plants were monitored daily for symptom appearance. The incidence of the disease (\%) was recorded as the number of diseased plants over the total number of plants in the experimental unit multiplied by a hundred. Plants treated only with sterile distilled water were used as the negative control. Incidences were contrasted based on the Score method, using the software R (Tippmann, 2015), to determine if there was a significant effect of inoculation on the incidence of damping-off.

The fungal isolate of $F$. oxysporum obtained from diseased plants of $P$. patula, from now on named strain $001 \mathrm{~F}$, was the only isolate that reproduced the original symptoms of damping-off, therefore was selected for pathogenicity tests. Its pathogenicity in P. tecunumanii plants was determined by nursery test. To do so, a comparison was made between three groups of plants sprouted 1) seeds inoculated with macerated diseased plants, 2) seeds inoculated with strain 001F spores as described, and 3) control plants from seeds without inoculum. Inoculation was performed one day before planting the seeds of $P$. tecunumanii. Briefly, $1.5 \mathrm{ml}$ of a suspension of $1 \times 10^{6}$ spores $/ \mathrm{ml}$ of strain $001 \mathrm{~F}$ or $2 \mathrm{ml}$ of a suspension from macerated diseased plants, was applied per each seed (Ownley \& Trigiano, 2016). Trays for germination of plants were disinfected with $1 \%$ hypochlorite and filled with autoclaved pine bark. Each experimental unit consisted of 25 P. tecunumanii plants in a tray, with three replications, for a total of 75 plants per each treatment. The incidence was recorded daily for 28 days. Data obtained were subjected to repeated measures analysis, using the SAS MIXED procedure, version 9.00. Before fitting the model, angular transformation was applied to the incidences.

\section{RESULTS}

\subsection{Morphological characterization of fungal isolate}

Five fungal isolates were obtained from symptomatic plant tissues. When re-inoculated, one isolate reproduced the original symptoms of damping-off observed in plants, the strain 001F. The remaining isolates did not produce symptoms. In the macroscopic observations, the pathogenic colony was characterized by the presence of an aerial mycelia that was initially white and changed to a purple-color over time. The colony grew fast covering the whole Petri dish in a period of 10 days and maintaining a radial pattern of growth (Figure 1). Under the microscope, a straight to slightly curved septate mycelium and relatively thin and thin-walled macroconidia with mean dimensions of 36 (standard deviation $(\mathrm{SD}) \pm 3.6) \mu \mathrm{m} X 3.2(\mathrm{SD} \pm 0.8) \mu \mathrm{m}$ and with 
three to five septa, were observed. Abundant oval shaped microconidia, without septa, with mean dimensions of $8(\mathrm{SD} \pm 2.3) \mu \mathrm{m}$ X $2.3(\mathrm{SD} \pm 0.5) \mu \mathrm{m}$, straight to curved, were also observed. In 14-days cultures, the presence of terminal and interspersed chlamydospores was observed (Figure 1). The macroscopic and microscopic observations were consistent with characteristics of the F. oxysporum species complex of fungus (van Dam et al., 2018; Fourie et al., 2011).

\subsection{Sequence analysis of the ITS regions and identification}

The amplification with universal ITS primers and the subsequent visualization of the PCR products by electrophoresis in agarose gel, revealed a 520 bp fragment. The sequence obtained from the amplicon of strain 001F was deposited in NCBI-GenBank with the submission number SUB5357489 and accession number MK680158. Comparison of the sequence with those deposited in the NCBI database revealed a 99\% similarity with the accession identified with code KT271765, corresponding to F. oxysporum. In addition, the sequence obtained clearly grouped with other 11 sequences of F. oxysporum retrieved from Genbank in the dendrogram made using the Maximum Likelihood method; meanwhile ITS sequences of other species of Fusarium distant from F. oxysporum and causing disease in Pinus spp. such as F. commune, F. proliferatum, F. circinatum, F. bactridioides and F. fujikuroi, formed different clusters (Figure 2). Together, morphological and molecular results confirm that our strain $001 \mathrm{~F}$ is within the F. oxysporum species complex.
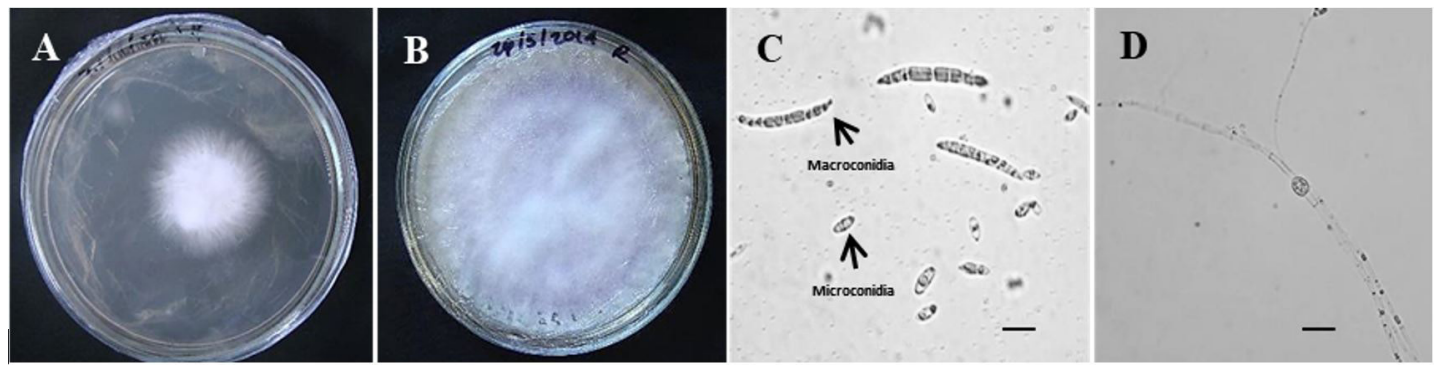

Figure 1. Morphological characterization. (A) The colony 3 days after seeding on agar plates; (B) The colony after 10 days of incubation; (C) Macroconidia and microconidia (100X); (D) Chlamydospores and hyphae with septa (60X). Fungal incubation was performed in Petri plates containing PDA at $28^{\circ} \mathrm{C}$. Scale bar: $10 \mu \mathrm{m}$.

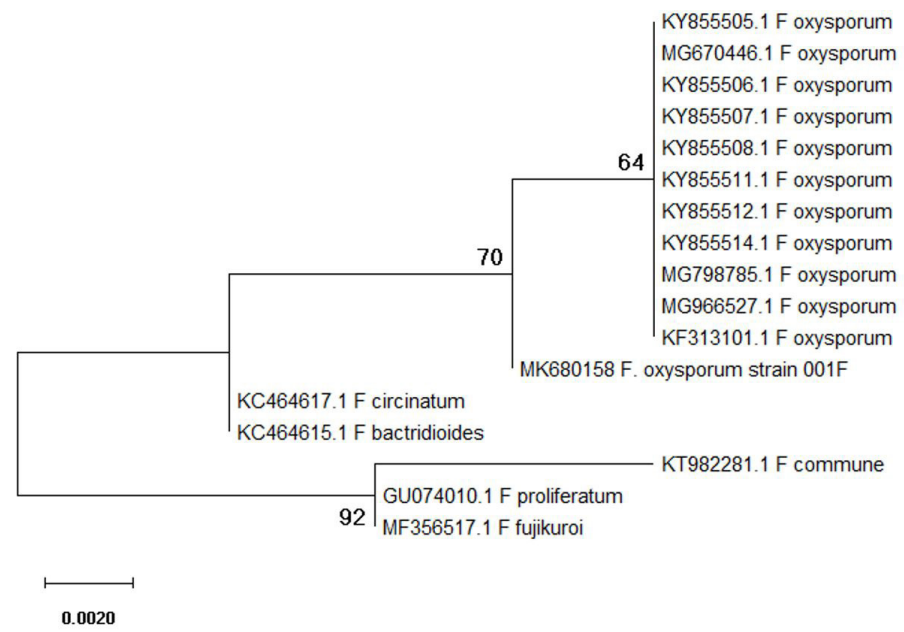

Figure 2. Sequence analyses of ITS regions of pathogenic isolate. Dendogram of Fusarium sequences was constructed by Maximum Likelihood method. Sequence codes correspond to Genbank accession number retrieved from NCBI using the Blastn algorithm. Numbers in branches mean Bootstrap values using 1000 iterations. Bootstrap values below 60 were deleted. Analyses were performed in MEGA X. 


\subsection{Plant symptomatology}

\subsubsection{Pathogenicity tests}

During the 23 days evaluated, no incidence of damping-off was observed in the control seedlings of $P$. patula not inoculated and treated only with sterile distilled water (Figure 3). In clear contrast, in the treatment of plants inoculated with the strain $001 \mathrm{~F}$, disease incidence gradually increased until reaching $85 \%$ after 23 days $(\mathrm{P}<0.0001)$ (Figure 4$)$. Together, these results suggest that F. oxysporum is the causative agent of the damping-off symptoms in P. patula (Figure 3 and 4). In this study, strain $001 \mathrm{~F}$ was re-isolated from inoculated and diseased tissues of $P$. patula, fulfilling the Koch postulates (Figure 3).

Similarly, plants of $P$. tecunumanii inoculated with the strain $001 \mathrm{~F}$ showed basal stem strangulation, light brown basal necrosis with an ascending tendency in the neck of the plant, and wilted needles with a tendency to present total necrosis, symptoms typical of damping-off (Figure 5). Damping-off in the 001F-inoculated plants, reached an incidence of $41.3 \% 23$ days after inoculation (Figure 6).
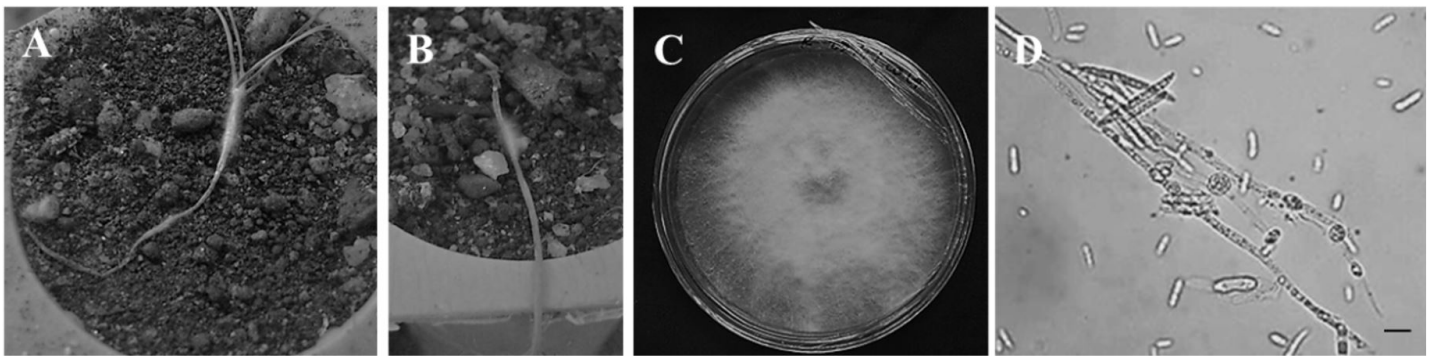

Figure 3. Koch postulates for the causal agent of damping-off in P.patula. (A) and (B) Disease symptoms in P.patula seedlings inoculated with the $001 \mathrm{~F}$ isolate of F. oxysporum; (C) Colony obtained by re-isolation of $001 \mathrm{~F}$ isolate from symptomatic tissues of inoculated $P$. patula seedlings; (D) Macroconidia, microconidia and chlamydospores of re-isolated $001 \mathrm{~F}$ isolate of F. oxysporum (60X). Photos are representative of results obtained from three replicates of 25 plants each for a total of 75 plants per treatment. Scale bar $=10 \mu \mathrm{m}$.

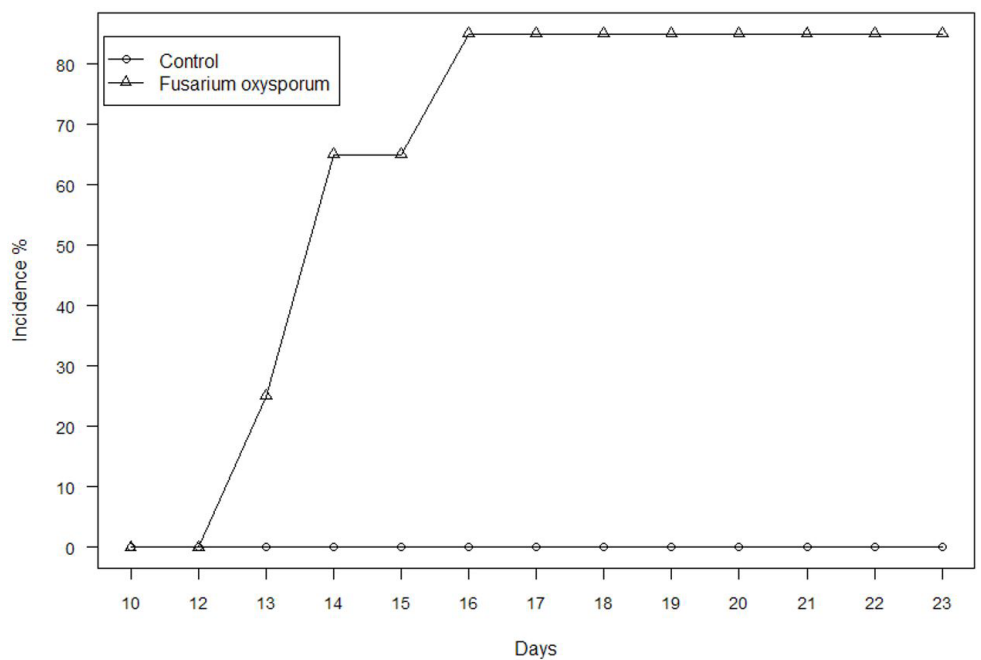

Figure 4. Incidence in percentage of damping-off in $P$. patula seedlings inoculated with the $001 \mathrm{~F}$ isolate of F. oxysporum. Each point represents the percentage of disease incidence calculated as the number of diseased plants divided by total plants multiplied by 100 . A total of three replicates of 25 plants each for a total of 75 plants were used per treatment. Circular points correspond to non-inoculated seedlings used as control. Triangular points represent plants inoculated with the $001 \mathrm{~F}$ isolate of F. oxysporum. Data obtained were subjected to repeated measures analysis, using the SAS MIXED procedure, version 9.00. Before fitting the model, angular transformation was applied to the incidences. 

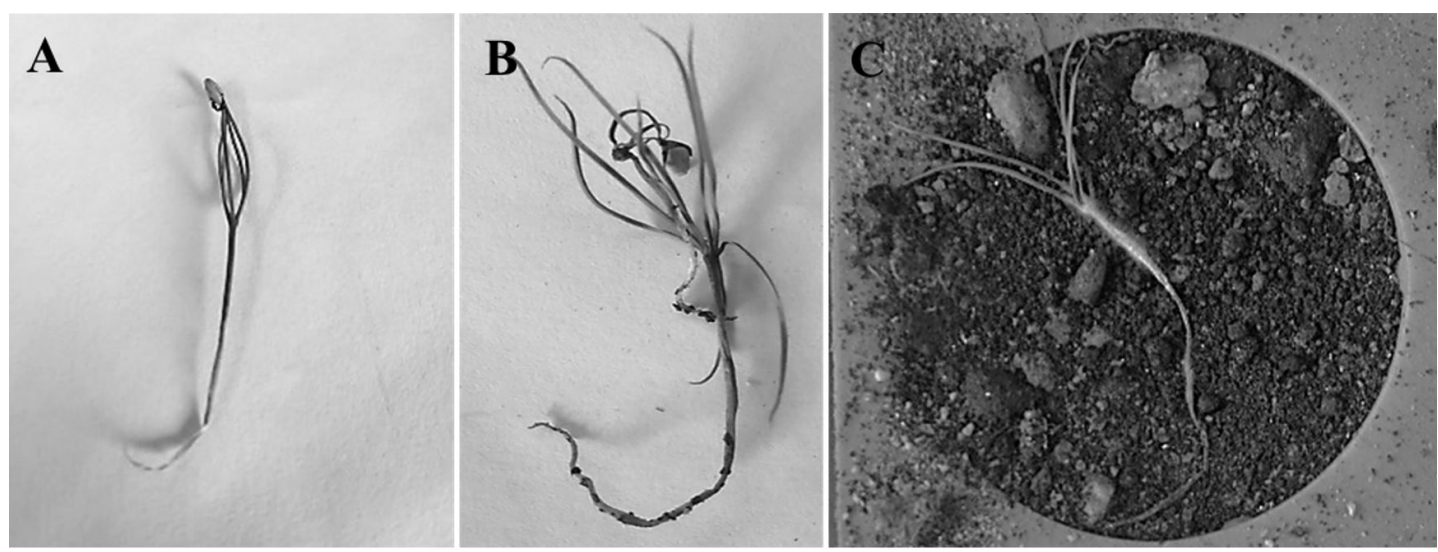

Figure 5. Symptoms of damping-off in P. tecunumanii seedlings. (A) Basal stem strangulation; (B) Basal stem rot; (C) Basal stem rot and sporulation. Photos are representative of results obtained from three replicates of 25 plants each for a total of 75 plants per treatment.

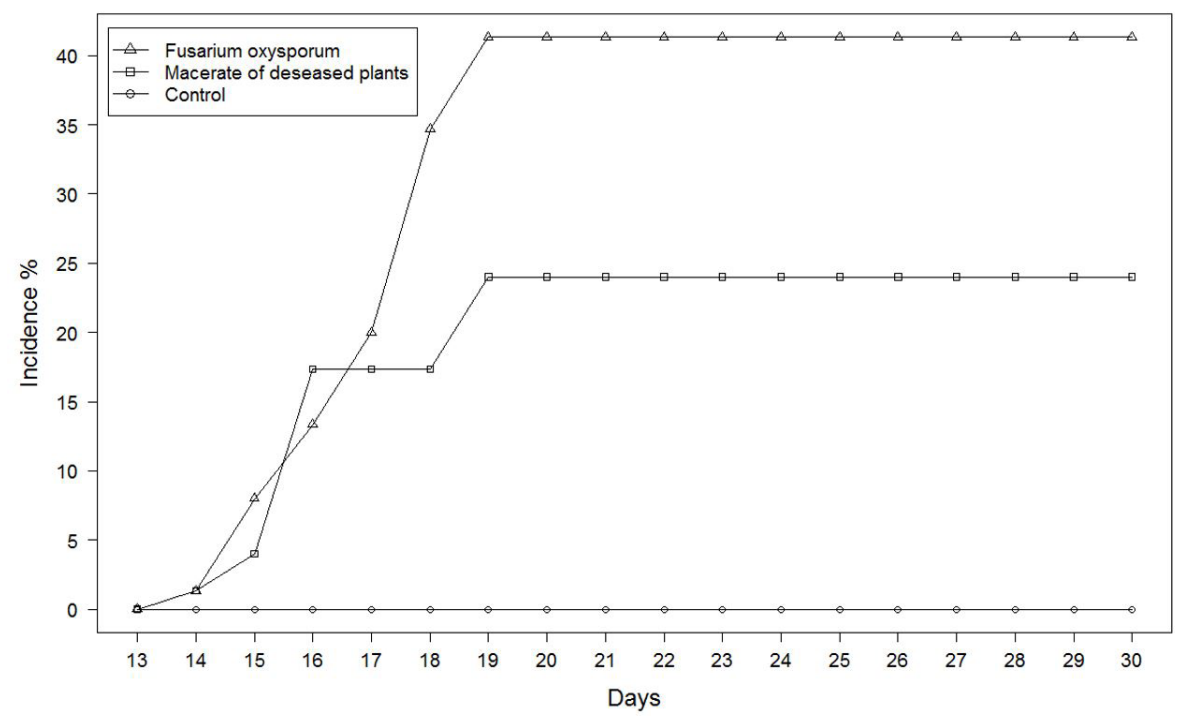

Figure 6. Incidence in percentage of damping-off in $P$. tecunumanii seedlings inoculated with the $001 \mathrm{~F}$ isolate of F. oxysporum. Each point represents the percentage of disease incidence calculated as the number of diseased plants divided by total plants multiplied by a 100. A total of three replicates of 25 plants each for a total of 75 plants were used per treatment. Circular points correspond to non-inoculated seedlings used as control. Triangular points represent plants inoculated with the $001 \mathrm{~F}$ isolate of F. oxysporum. Data obtained were subjected to repeated measures analysis, using the SAS MIXED procedure, version 9.00. Before fitting the model, angular transformation was applied to the incidences.

The control seedlings of $P$. tecunumanii irrigated with sterile distilled water only did not present symptomatology of the disease. There was a highly significant difference in the incidence of damping-off $(\mathrm{P}=0.0004)$ between the plants inoculated with strain $001 \mathrm{~F}$ and the control plants (Figure 6). The strain 001F of F. oxysporum was isolated repeatedly from seedlings with symptoms of damping-off produced under these commercial production conditions. No other pathogens were isolated using this procedure.

\section{DISCUSSION}

The development of this work allowed us to isolate the strain $001 \mathrm{~F}$ of the fungus $F$. oxysporum and identify it as a causal agent of damping-off in two 
Pinus species in Colombia. In support of our findings, there are numerous reports of this pathogen affecting other forest species (Morris et al., 2014; Herrón et al., 2015; Gordon et al., 2015; Fajardo-Mejía et al., 2016). We identified this species by morphological and molecular criteria (Fourie et al., 2011; van Dam et al., 2018). Additionally, pathogenicity tests were performed.

The pathogenicity tests for the two pine species evaluated showed conclusively that the strain $001 \mathrm{~F}$ is capable of producing the symptoms of the disease in $P$. patula and $P$. tecunumanii seedlings. Similar results were found by Stewart et al. (2012), where they found that different isolates of F. oxysporum and F. commune obtained from healthy and diseased seedlings of Douglas fir (Pseudotsuga menziesii (Mirb.) Franco) and western white pine (Pinus monticola (Douglas ex Don) were able to reproduce the symptoms of damping-off in Douglas fir seedlings under greenhouse conditions. Similarly, Herrón et al., (2015) were able to isolate F. oxysporum and F. parvisorum (Herron, Marinc. and Wingf.) from diseased nursery seedlings of the genus Pinus. Additionally, other researchers found that different isolates of the genus Fusarium, obtained from pine seedlings, are pathogenic for seedlings of P. patula (Fitza et al., 2013).

On the other hand, the seedlings of $P$. tecunumanii inoculated with the macerate of diseased plants presented a lower incidence of the disease. Damping-off is a disease caused by a complex of pathogens (Lazreg et al., 2014; Weiland et al., 2014; Gordon et al., 2015) and when inoculating with the macerate of diseased plants it is probable that other pathogenic and not pathogenic microorganisms that may compete between them, be involved in the effect observed. A question remains to be answered about if this is the only causal agent or maybe there are others. In the present work, only strain $001 \mathrm{~F}$ of $F$. oxysporum was isolated, however, as mentioned, damping-off may be caused by several plant pathogenic microorganisms. Therefore, other causal agents of damping-off should not be discarded when managing this disease in plantations around the country and accurate diagnosis should be performed in each particular case.

Phytosanitary analysis revealed that the inoculum of the disease can have various sources of origin such as seeds, irrigation water, and the substrate used, where pathogenic fungi such as F. oxysporum were present
(Fajardo-Mejía et al., 2016; Lamichhane et al., 2017). Additionally, F. oxysporum produces a large amount of chlamydospores that allow it to survive in the soil for long periods of time, as well as in dead tissue of the host plant, and in plant remnants in the soil in the absence of a host plant, making it difficult to control (Gordon et al., 2015). In addition, Jones et al. (2014), found that high concentrations of inoculum caused higher mortality levels in P. patula seedlings. For these reasons, the handling of damping-off should be focused on avoiding the arrival of infectious propagules of the pathogen to the growth substrates used in the nursery, as well as in an early detection.

Several investigations found that conifer trees obtained from seedlings that presented damping-off caused by Fusarium spp. can suffer significant damage from resinous canker in the field (Stewart et al., 2012; Steenkamp et al., 2012; Jones et al., 2014). This could be attributed to the fact that the pathogen can be latent in the transplanted seedling; therefore, an early detection of these pathogens would be crucial to avoid sending them to the field (Jones et al., 2014).

In our study a single species was identified causing disease, however it is very important because little information is known about causal agents of Pinus diseases in Colombia. Therefore, this knowledge is crucial for proper management. Future research including more areas and nurseries for Pinus spp. production are needed to identify the different pathogens that affect the conifers and other gymnosperms native to Colombia and to study the susceptibility to these pathogens, allowing the development of adequate control strategies. This will require detailed knowledge about the distribution, host range and pathogen ecology.

In Colombia, the identification of strain $001 \mathrm{~F}$ of F. oxysporum as the causal agent of damping-off in $P$. patula and $P$. tecunumanii is just the beginning of what is necessary to aid in the making of phytosanitary recommendations and control strategies adjusted especially for the traditional nursery management of seedlings. Of particular importance is the precise identification of the different disease-causing agents, since, for example, some chemical products that are effective in oomycete microorganisms, are not effective in fungi. For this reason, an incorrect identification of the causal agent entails an increase in costs, due to the application of control measures that are not effective 
and also pollute the environment and can affect public health. This work may be used as a model for causal agent identification in forestry plantations in Colombia.

\section{ACKNOWLEDGEMENTS}

Universidad Nacional de Colombia sede Medellín and Compañía Agrícola la Sierra for funding.

\section{SUBMISSION STATUS}

Received: 5 apr., 2019

Accepted: 24 sept., 2019

\section{CORRESPONDENCE TO}

\section{Juan Gonzalo Morales}

Departamento de Ciencias Agronómicas, Universidad Nacional de Colombia - sede Medellín, Carrera 65, No 59A-110, Bloque 11, oficina 117-13

Medellin, Antioquia, Colombia, 050034 e-mail: jgmoralesos@unal.edu.co

\section{FINANCIAL SUPPORT}

Universidad Nacional de Colombia sede Medellín (DIME, Hermes code number 20511).

\section{REFERENCES}

Carrasco A, Sanfuentes E, Durán Á, Valenzuela S. Pitch canker disease a potential threat to Pinus radiata plantations in Chile? Gayana. Botánica 2016; 73(2): 369-380. http:// dx.doi.org/10.4067/S0717-66432016000200369.

Claros Cuadrado JL, Baltazar Castañeda H, Trujillo Cuellar F, Flores MA. Natural durability of Pinus oocarpa and Pinus tecunumanii wood from forest stands in San Alberto, Oxapampa. Revista Forestal del Perú 2017; 32(2): 70-77. http://dx.doi.org/10.21704/rfp.v32i2.1038.

Dar GH, Beig MA, Ahanger FA, Ganai NA, Ahangar MA. Management of root rot caused by Rhizoctonia solani and Fusarium oxysporum in blue pine (Pinus wallichiana) through use of fungal antagonists. Asian Journal of Plant Pathology 2011; 5(2): 62-67. http://dx.doi.org/10.3923/ ajppaj.2011.62.74.

Dean R, Van Kan J, Pretorius Z, Hammond-Kosack K, Di Pietro A, Spanu P et al. The Top 10 fungal pathogens in molecular plant pathology. Molecular Plant Pathology
2012; 13(4): 414-430. http://dx.doi.org/10.1111/j.13643703.2011.00783.x. PMid:22471698.

Fajardo-Mejía MA, Morales-Osorio JG, Antonio G, LeónPeláez JD. Effect of plant extracts and growth substrates on controlling damping-off in Pinus tecunumanii seedlings. Cerne 2016; 22(3): 317-324. http://dx.doi.org/10.1590/0 1047760201622032150.

Felsenstein J. Confidence limits on phylogenies: an approach using the bootstrap. Evolution; International Journal of Organic Evolution 1985; 39(4): 783-791. http://dx.doi. org/10.1111/j.1558-5646.1985.tb00420.x. PMid:28561359.

Fitza KN, Payn KG, Steenkamp ET, Myburg AA, Naidoo S. Chitosan application improves resistance to Fusarium circinatum in Pinus patula. South African Journal of Botany 2013; 85: 70-78. http://dx.doi.org/10.1016/j.sajb.2012.12.006.

Flores-Pacheco JA. Pitch canker disease (Fusarium circinatum) history, evolution, dispersion and management strategies. Nexo Revista Científica 2017; 30(01): 19-42. http://dx.doi.org/10.5377/nexo.v30i01.5170.

Fourie G, Steenkamp E, Ploetz R, Gordon T, Viljoen A. Current status of the taxonomic position of Fusarium oxysporum formae specialis cubense within the Fusarium oxysporum complex. Infection, Genetics and Evolution 2011; 11(3): 533-554. http://dx.doi.org/10.1016/j. meegid.2011.01.012. PMid:21256980.

García Díaz SE, Aldrete A, Alvarado-Rosales D, CibriánTovar D, Méndez-Montiel JT, Valdovinos-Ponce G et al. Effect of Fusarium circinatum on the germination and growth of Pinus greggii seedlings on three substrates. Agrociencia 2017; 51(8): 895-908.

García Díaz SE, Cibrián Tovar D. Root rot caused by Fusarium oxysporum Schltdl in conifers. In Memoria del XV Simposio Nacional de Parasitología Forestal; 2011; Oaxaca, México. México: Colegio de Postgraduados; 2011. p. 204-207.

Gómez EA, Ríos LA, Peña JD. Madera, un potencial material lignocelulósico para la producción de biocombustibles en Colombia. Información Tecnológica 2012; 23(6): 73-86. http://dx.doi.org/10.4067/S0718-07642012000600009.

González B, Pintos C, Mansilla J, Aguín O, Pérez R. Presencia de especies de Fusarium sobre semillas de Pinus spp. en Galicia. Cuadernos de la Sociedad Española de Ciencias Forestales 2008; 26: 149-154.

Gordon TR, Swett CL, Wingfield MJ. Management of Fusarium diseases affecting conifers. Crop Protection (Guildford, Surrey) 2015; 73: 28-39. http://dx.doi. org/10.1016/j.cropro.2015.02.018.

Herrón DA, Wingfield MJ, Wingfield BD, Rodas CA, Marincowitz S, Steenkamp ET. Novel taxa in the Fusarium fujikuroi species complex from Pinus spp. Studies in Mycology 2015; 80: 131-150. http://dx.doi.org/10.1016/j. simyco.2014.12.001. PMid:26955193. 
Jones N, Ford CM, Light ME, Nadel RL, Greyling I, Fourie $\mathrm{G}$ et al. Effect on nursery and field performance of Pinus patula seedlings after inoculation with Fusarium circinatum. Southern Forests 2014; 76(3): 125-136. http:// dx.doi.org/10.2989/20702620.2014.916503.

Kanzler A, Nel A, Ford C. Development and commercialisation of the Pinus patula $\mathrm{x}$ P. teucnumanii hybrid in response to the threat of Fusarium circinatum. New Forests 2014; 45(3): 417-437. http://dx.doi.org/10.1007/s11056-014-9412-1.

Kumar S, Stecher G, Li M, Knyaz C, Tamura K. MEGA X: molecular evolutionary genetics analysis across computing platforms. Molecular Biology and Evolution 2018; 35(6): 1547-1549. http://dx.doi.org/10.1093/molbev/msy096. PMid:29722887.

Lamichhane J, Dürr C, Schwanck A, Robin M, Sarthou J, Cellier V et al. Integrated management of damping-off diseases. Agronomy for Sustainable Development 2017; 37(2): 10. http://dx.doi.org/10.1007/s13593-017-0417-y.

Lazreg F, Belabid L, Sanchez J, Gallego E, Garrido-Cardenas J, Elhaitoum A. First report of Fusarium equiseti Causing damping-off disease on Aleppo pine in Algeria. Plant Disease 2014; 98(9): 1268-1268. http://dx.doi.org/10.1094/ PDIS-02-13-0194-PDN. PMid:30699642.

López-López N, Segarra G, Vergara O, López-Fabal A, Trillas MI. Compost from forest cleaning green waste and Trichoderma asperellum strain T34 reduced incidence of Fusarium circinatum in Pinus radiata seedlings. Biological Control 2016; 95: 31-39. http://dx.doi.org/10.1016/j. biocontrol.2015.12.014.

Machón P, Pajares JA, Diez JJ, Alves-Santos FM. Influence of the ectomycorrhizal fungus Laccaria laccata on preemergence, post-emergence and late damping-off by Fusarium oxysporum and F. verticillioides on Stone pine seedlings. Symbiosis 2009; 49(2): 101-109. http://dx.doi. org/10.1007/s13199-009-0015-0.

Maphosa MN, Steenkamp ET, Wingfield BD. Genome-based selection and characterization of Fusarium circinatumspecific sequences. G3 (Bethesda) 2016; 6(3): 631-639. PMid:26888868.

Martínez-Álvarez P, Fernández-González RA, Sanz-Ros AV, Pando V, Diez JJ. Two fungal endophytes reduce the severity of pitch canker disease in Pinus radiata seedlings. Biological Control 2016; 94: 1-10. http://dx.doi.org/10.1016/j. biocontrol.2015.11.011.

Martín-Rodrigues N, Sanchez-Zabala J, Salcedo I, Majada J, González-Murua C, Duñabeitia MK. New insights into Pinus radiata seedling root infection by Fusarium circinatum. Plant Pathology 2015; 64(6): 1336-1348. http:// dx.doi.org/10.1111/ppa.12376.

Morris AR, Fourie G, Greyling I, Steenkamp ET, Jones NB. Re-use of seedling containers and Fusarium circinatum association with asymptomatic Pinus patula planting stock. Southern Forests 2014; 76(3): 177-187. http://dx.doi.org/ $10.2989 / 20702620.2014 .957491$.
National Center for Biotechnology Information - NCBI. U.S. National Library of Medicine [online]. USA: NBCI; 2019 [cited 2019 Sept 5]. Available from: http: // ncbi. nlm.nih.gov/BLAST

Ownley B, Trigiano R. Plant pathology concepts and laboratory exercises. 3rd ed. London: CRC Press; 2016.

Pérez A, Hermosa R, Monte E. Biocontrol activities of Trichoderma against phytopathogenic ascomycetes. Farma Journal 2017; 1(2): 85-93.

Program on Forests - PROFOR. Situación actual y potenciales de fomento de plantaciones forestales con fines comerciales en Colombia. Colombia: Reforestación Comercial Potencial del Banco Mundial/PROFOR; 2017. Informe final del Programa.

Sánchez-Cuervo AM, Aide TM, Clark ML, Etter A. Land cover change in colombia: surprising forest recovery trends between 2001 and 2010. PLoS One 2012; 7(8): e43943. http://dx.doi.org/10.1371/journal.pone.0043943. PMid:22952816.

Santos A, Trindade J, Lima C, Barbosa R, Costa A, Tiago $\mathrm{P}$ et al. Morphology, phylogeny, and sexual stage of Fusarium caatingaense and Fusarium pernambucanum, new species of the Fusarium incarnatum-equiseti species complex associated with insects in Brazil. Mycologia 2019; 29(2): 1-16. http://dx.doi.org/10.1080/00275514.2019.15 73047. PMid:30924728.

Seseni L, Regnier T, Roux-van der Merwe MP, Mogale E, Badenhorst J. Control of Fusarium spp. causing dampingoff of pine seedlings by means of selected essential oils. Industrial Crops and Products 2015; 76: 329-332. http:// dx.doi.org/10.1016/j.indcrop.2015.07.002.

Steenkamp ET, Rodas CA, Kvas M, Wingfield MJ. Fusarium circinatum and pitch canker of Pinus in Colombia. Australasian Plant Pathology 2012; 41(5): 483-491. http:// dx.doi.org/10.1007/s13313-012-0120-z.

Stewart JE, Abdo Z, Dumroese RK, Klopfenstein NB, Kim MS. Virulence of Fusarium oxysporum and F. commune to Douglas-fir (Pseudotsuga menziesii) seedlings. Forest Pathology 2012; 42(3): 220-228. http://dx.doi.org/10.1111/ j.1439-0329.2011.00746.x.

Swett CL, Reynolds GJ, Gordon TR. Infection without wounding and symptomless shoot colonization of Pinus radiata by Fusarium circinatum, the cause of pitch canker. Forest Pathology 2018; 48(3):1-7. https://doi.org/10.1111/ efp.12422.

Tippmann S. Programming tools: adventures with R. Nature 2015; 517(7532): 109-110. http://dx.doi. org/10.1038/517109a. PMid:25557714.

Tuffley C, Timothy W, White J, Hendy M, Penny D. Correcting the apparent mutation rate acceleration at shorter time scales under a Jukes-Cantor model. Molecular Biology and Evolution 2012; 29(12): 3703-3709. http:// dx.doi.org/10.1093/molbev/mss172. PMid:22790671. 
Unidad de Planificación Rural Agropecuaria - UPRA. Lineamientos de política: plantaciones forestales con fines comerciales para la obtención de madera y su cadena productiva. Bogotá: UPRA; 2018 [cited 2019 Apr 5]. Available from: https://www.upra.gov.co/documents/10184/13821/ PLANTACIONES+FORESTALES+CON+FINES+CO MERCIALES+PARA+LA+OBTENCI\%C3\%93N+DE+ MADERA+Y+SU+CADENA+PRODUCTIVA/051c6f bc-ae53-4bf6-8e45-a0d64939c391?version=1.1

van Dam P, de Sain M, ter Horst A, van der Gragt M, Rep M. Use of comparative genomics-based markers for discrimination of host specificity in Fusarium oxysporum. Applied and Environmental Microbiology 2018; 84(1): e01868-e17. PMid:29030446.

Vivas M, Martín JA, Gil L, Solla A. Evaluating methyl jasmonate for induction of resistance to Fusarium oxysporum, F. circinatum and Ophiostoma novo-ulmi. Forest Systems 2012; 21(2): 289-299. http://dx.doi.org/10.5424/fs/2012212-02172.
Weiland JE, Santamaria L, Grünwald NJ. Sensitivity of Pythium irregulare, P. sylvaticum, and P. ultimum from forest nurseries to mefenoxam and fosetyl- $\mathrm{Al}$, and control of Pythium damping-off. Plant Disease 2014; 98(7): 937942. http://dx.doi.org/10.1094/PDIS-09-13-0998-RE. PMid:30708838.

White TJ, Bruns T, Lee S, Taylor J. Amplification and direct sequencing of fungal rRNA genes for phylogenetics. In: Innis AM, Gelfand DH, Sninsky JJ, White TJ, editors. PCR protocols: a guide to methods and applications. San Diego: Academic Press; 1990. p. 315-322.

Zuo C, Li C, Li B, Wei Y, Hu C, Yang Q et al. The toxic mechanism and bioactive components of Chinese leek root exudates acting against Fusarium oxysporum f. sp. cubense tropical race 4. European Journal of Plant Pathology 2015; 143(3): 447-460. http://dx.doi.org/10.1007/s10658015-0697-5. 